\title{
1-Methylcyclopropene Applications in Preharvest Systems: Focus on Citrus
}

\author{
Jacqueline K. Burns ${ }^{1}$ \\ University of Florida, IFAS, Horticultural Sciences Department, Citrus Research and Education Center, \\ 700 Experiment Station Road, Lake Alfred, FL 33850
}

Additional index words. ethephon, ethylene, fruit detachment force, leaf abscission, mature fruit loosening plant growth regulator application

\begin{abstract}
Methylcyclopropene (1-MCP) is a gaseous ethylene-binding inhibitor used to control or delay ethylene-related postharvest effects in a range of horticultural commodities. The potential for preharvest applications of 1-MCP to prevent unwanted defoliation using ethephon to loosen mature citrus fruit is presented. Although there was no difference in mature fruit loosening by ethephon + 1-MCP treatments, 1-MCP reduced defoliation caused by ethephon. The gaseous nature of 1-MCP is an impediment to uniform application and consistent efficacy. A sprayable 1-MCP formulation would be of great value for preharvest use in many horticultural crops.
\end{abstract}

The gaseous compound 1-methylcyclopropene (1-MCP) is becoming an invaluable tool to abate undesirable ethylene effects in horticultural commodities. In particular, ethylene-related postharvest physiological effects in climacteric fruit, leaf and flower abscission in floricultural commodities, and, in some instances, fruit decay have been reduced by postharvest $1-\mathrm{MCP}$ application. 1 -MCP is odorless, colorless, effective at low concentrations, and persistent in its effects in many crops (Blankenship and Dole, 2003; Watkins, 2006). The discovery of compounds such as 1-MCP that block ethylene binding to membrane-bound ethylene receptors have changed the way agricultural commodities are handled (Sisler, 2006).

Although horticultural commodities have benefited from postharvest use of 1-MCP, the potential for commodity improvements with preharvest applications of this plant growth regulator are only now being addressed. Progress in this area has been limited by the difficulty in successfully applying gaseous 1-MCP to plants in the field. Commodities that may benefit most from preharvest 1-MCP applications are those negatively impacted by ethylene exposure but do not have the desired response to compounds that inhibit ethylene biosynthesis. In these cases, ethylene may originate from neighboring plants, organs, or tissues or from application of exogenous compounds that generate ethylene such as ethephon (Warner and Leopold, 1969). This review focuses on minimizing unwanted phytotoxicity using 1-MCP when ethephon is used to cause loosening in mature citrus fruit.

\footnotetext{
This research was supported by the Florida Agricultural Experiment Station, Florida Citrus Initiative Funds, and the Florida Department of Citrus. We thank AgroFresh Inc. for supplying 1-MCP in the form of SmartFresh ${ }^{\circledR}$

Use of trade name does not imply endorsement of the products named or criticism of similar ones not named.

${ }^{1}$ To whom correspondence should be addressed; e-mail jkbu@ufl.edu
}

\section{LEAVES AND MATURE FRUIT DIFFERENTIALLY RESPOND TO 1-METHYLCYCLOPROPENE + ETHEPHON IN THE FIELD}

Ethephon is frequently a starting point for most screening programs because it is registered for use on several food crops and is relatively inexpensive to purchase and apply. However, the high ethephon concentration necessary to loosen mature fruit effectively caused excessive defoliation (Fig. 1), and phytotoxicity increased with increasing temperatures (Yuan and Burns, 2004). Because ethylene is chemically derived from ethephon, preharvest 1-MCP applications were tested to determine if unwanted defoliation could be reduced. The differential response of leaves and fruit to 1-MCP + ethephon was discovered during a screen for selective abscission compounds for citrus.

Combining $5 \mathrm{~mm}$ 1-MCP with $400 \mathrm{mg} \cdot \mathrm{L}^{-1}$ ethephon in the spray tank reduced ethephoninduced defoliation (Table 1). The ethylene biosynthesis inhibitor aminovinyl glycine at $1 \mathrm{~mm}$ had no effect on ethephon-induced defoliation, demonstrating that ethylene derived from ethephon and not from ethephon-induced ethylene biosynthesis induced leaf loss. Proper timing of 1-MCP sprays was important to maintain maximum control of ethephon-induced leaf abscission. Combining ethephon and 1-MCP in the spray tank followed by immediate application to citrus canopies was more effective than applying 1-MCP $24 \mathrm{~h}$ before or $24 \mathrm{~h}$ after ethephon treatment (Fig. 2). Concentrations from 1 to 5 mм 1-MCP markedly reduced ethephoninduced leaf abscission. Continued research revealed that variations in control of leaf abscission could be reduced using $5 \mathrm{~mm}$ 1-MCP, and most subsequent applications in the field were used at this concentration.

If the combined 1-MCP + ethephon treatment was to be considered as a viable combination for a citrus abscission agent, the impact of 1-MCP on ethephon-induced mature fruit loosening must be minimal. Fruit loosening as measured by the reduction in fruit detachment force was not reduced by 1-MCP alone, but ethephon and ethephon + 1-MCP loosened fruit similarly (Fig. 3).
Thus, 1-MCP did not impact ethephoninduced fruit loosening, although leaf abscission was controlled by the same application. Similar results were shown when whole citrus plants were treated for $16 \mathrm{~h}$ with gaseous 1-MCP before continuous ethylene exposure for 1 week (Burns et al., 2003). Leaf loss was significantly reduced by 1-MCP, but fruit drop was not impacted (Table 2).

\section{WHAT IS THE BASIS OF THE DIFFERENTIAL RESPONSE TO ETHEPHON + 1-METHYLCYCLOPROPENE?}

It is unknown why mature citrus fruit and leaves respond differentially to 1-MCP when combined with ethephon (or ethylene). Mature cherry fruit loosen when ethephon is applied, and this loosening was not impacted by $1-\mathrm{MCP}$ when applied in the field immediately before ethephon (Don Elfving, Washington State University, personal communication). Ethephon is used as a loosening agent for mechanical harvesting of cherries, and combined applications of ethephon with $1-\mathrm{MCP}$ reduced undesirable fruit softening. Byers et al. (2005) was unable to reduce preharvest mature apple fruit drop with preharvest 1-MCP treatment, although other ethylene-associated processes such as fruit softening were retarded. Abscission in some mature tree fruit is not altered by $1-\mathrm{MCP}$ when applied in this manner. As work in this area continues, differential organ responses to 1-MCP may be found in other horticultural crops. In contrast to fruit attached to the tree, harvested mature fruit (i.e., fruit explants) can behave differently to 1-MCP treatment. For example, ethylene-induced abscission in citrus and persimmon fruit explants could be reduced by 1-MCP exposure (Nakano et al., 2003; Porat et al., 1999, 2001).

It is unclear why abscission of fruit attached to the tree behaves differently from fruit explants or why leaves respond to $1-\mathrm{MCP}$ but mature tree fruit respond poorly. Leaves and fruit explants may be more sensitive to ethylene. Sensitivity to ethylene in tissues is believed to be governed by the number of ethylene receptors (Klee, 2002). 

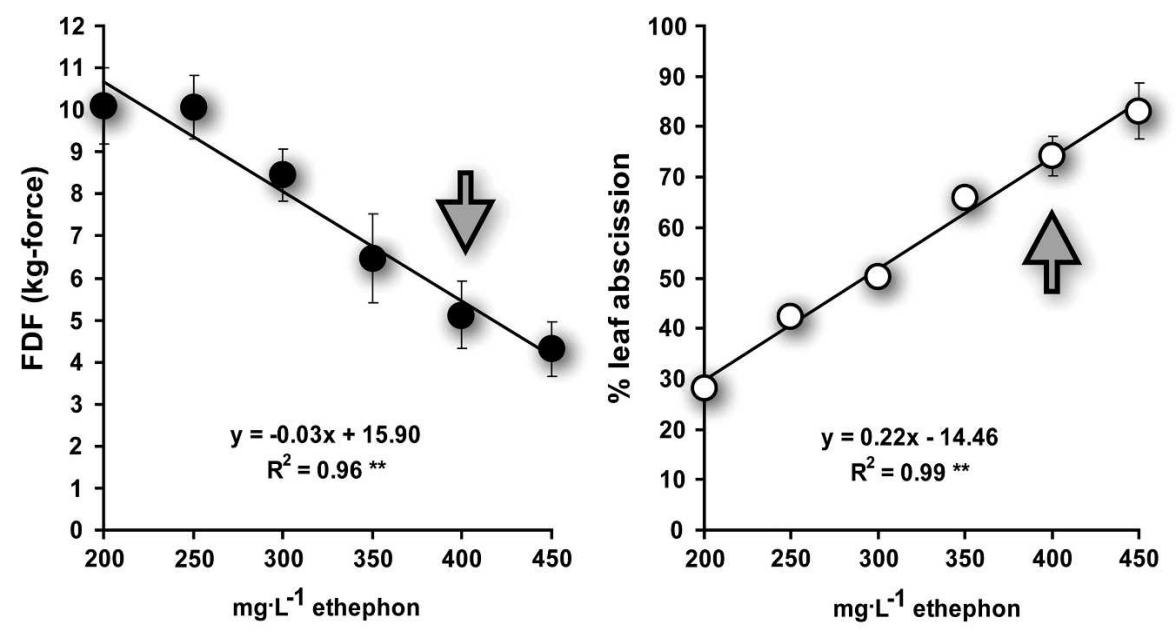

Hamlin orange

Fig. 1. Fruit detachment force (FDF, left graph) and percentage (\%) leaf abscission (right graph) 5 and $15 \mathrm{~d}$ after application of $400 \mathrm{mg} \cdot \mathrm{L}^{-1}$ ethephon, respectively, in 'Hamlin' orange. Arrows indicate the concentration of ethephon needed to reduce FDF to maximize mechanical harvesting efficiency. Graphs redrawn from Pozo et al. (2004).

Table 1. The effect of ethephon, AVG, 1-MCP, and adjuvant on percent leaf drop of Valencia orange (Citrus sinensis).

\begin{tabular}{lc}
\hline Treatment $^{z}$ & $\begin{array}{r}\text { Percent leaf } \\
\text { drop, day } 7^{\mathrm{y}}\end{array}$ \\
\hline Ethephon & $64.2 \mathrm{a}$ \\
Ethephon + AVG & $65.8 \mathrm{a}$ \\
Ethephon + 1-MCP & $10.8 \mathrm{~b}$ \\
Ethephon + AVG + 1-MCP & $7.7 \mathrm{~b}$ \\
AVG + 1-MCP & $8.3 \mathrm{~b}$ \\
AVG & $7.5 \mathrm{~b}$ \\
1-MCP & $9.8 \mathrm{~b}$ \\
Adjuvant control & $8.3 \mathrm{~b}$ \\
\hline
\end{tabular}

${ }^{\mathrm{z}}$ Applications: ethephon $400 \mathrm{mg} \cdot \mathrm{L}^{-1}, \quad$ AVG (aminovinyl glycine) $1 \mathrm{~mm}$; 1-MCP $5 \mathrm{~mm}$; adjuvant (Kinetic) $0.1 \%$.

${ }^{\mathrm{y}}$ Leaf drop means followed by the same letter are not significantly different $(P \leq 0.05)$.

$1-\mathrm{MCP}=1$-methylcyclopropene.
Based on the dogma of negative receptor regulation predicted for ethylene binding and downstream signaling, lower receptor number would result in greater tissue sensitivity to ethylene. Leaves may have intrinsically lower receptor numbers than mature fruit. Moreover, mature fruit could have a higher capacity to turn over or increase receptor number, and such a turnover rate may be influenced by ethylene. Consequently, 1-MCP applications would not be as efficacious in tissues with new, unbound ethylene receptors.

In its current state of technology, field quently) cannot guarantee that the a.i. remains in the atmosphere surrounding target tissues to insure binding to receptors. Tissues application of gaseous 1-MCP (see subse-

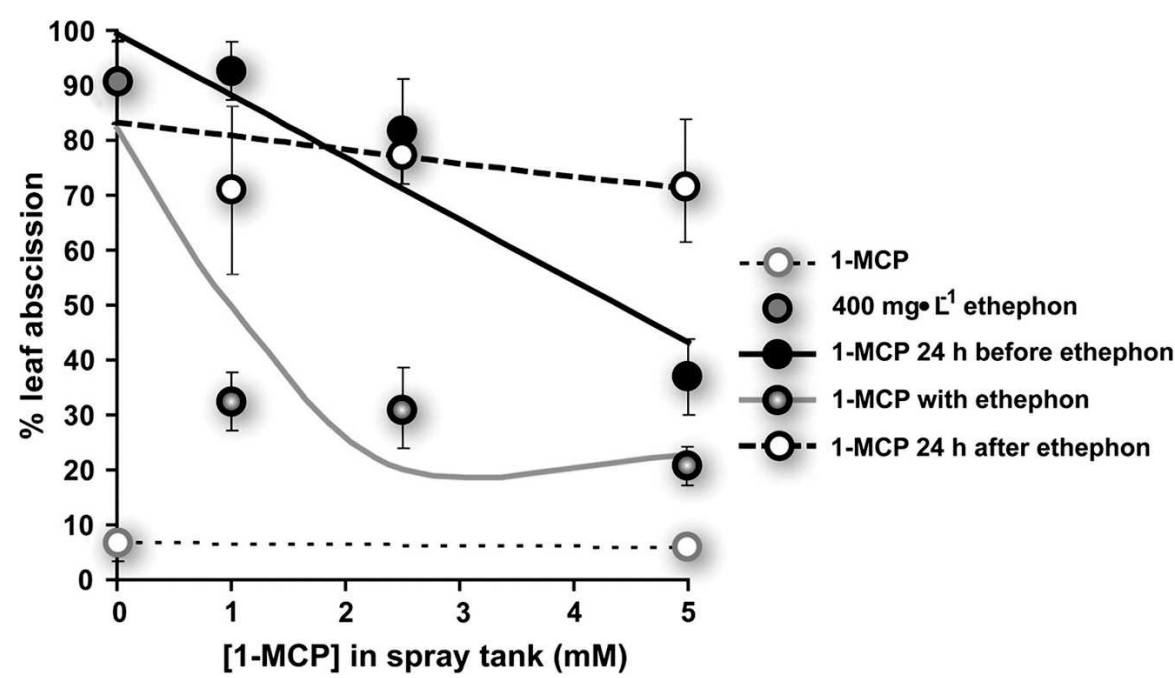

Fig. 2. Effect of 1-methylcyclopropene (1-MCP) concentration and spray timing on percentage leaf abscission $30 \mathrm{~d}$ after application of $1-\mathrm{MCP}+400 \mathrm{mg} \cdot \mathrm{L}^{-1}$ ethephon, $400 \mathrm{mg} \cdot \mathrm{L}^{-1}$ ethephon, and $5 \mathrm{~mm}$ $1-\mathrm{MCP}$ in 'Hamlin' orange. Timing of 1-MCP treatments were $24 \mathrm{~h}$ before, $24 \mathrm{~h}$ after, or simultaneously with ethephon. Concentrations of 1-MCP in ethephon combinations were 1, 2.5, and $5 \mathrm{~mm}$. Graphs redrawn from Pozo et al. (2004). with lower receptor number may have a higher probability of 1-MCP binding under these conditions. Ease of 1-MCP penetration into thin or more gas-permeable tissues such as leaves could increase the likelihood of receptor binding. Differential response could also be the result of differences in receptor types between leaves and mature fruit. In general, plant ethylene receptors can be subdivided into two subfamilies based on the presence or absence of conserved domains characteristic of histidine kinases (Chow and McCourt, 2006). It appears that 1-MCP binds equally to these receptor types (Hall et al., 2000), but emerging evidence suggests that there are specialized roles for receptor type signal output (O'Malley et al., 2005). Finally, there could be ethylene receptors yet to be discovered that are unique to mature fruit tissues that do not efficiently bind 1-MCP. Whatever the mechanism of differential response, ethephonassociated leaf abscission and other phytotoxic effects such as gummosis in citrus (Pozo and Burns, 2000) can be predictably decreased with 1-MCP. This can be exploited to adapt ethephon for use in situations in which ethephon application alone is not suitable.

\section{FIELD APPLICATION OF 1-METHYLCYCLOPROPENE}

Although field application of 1-MCP has been successful in research trials, it is not yet commercially viable or registered for field use. Numerous challenges to commercial field application exist. 1-MCP is formulated as a wettable powder. The wettable powder is marketed as SmartFresh (AgroFresh; Rohm and Haas, Philadelphia, PA) and is intended only for postharvest use in registered commodities. On hydration of the wettable powder, the a.i. in SmartFresh is released as a gas. In storage rooms or other enclosed areas, the amount of 1-MCP released into the atmosphere surrounding a commodity can be calculated and duration of exposure controlled (Blankenship and Dole, 2003). In contrast, the amount delivered to target tissues and duration of exposure with field applications of 1-MCP is not known. Successful applications have been determined by trial and error and prepared solutions defined in terms of amount of a.i. dissolved in the spray solution applied in the field. Generally, an excessive amount of 1-MCP is used in field applications to achieve efficacy because the amount that actually reaches the target is unknown.

In citrus, acceptable control of ethephoninduced leaf abscission can be accomplished by dissolving 1-MCP in a spray tank containing an ethephon solution and the resulting solution immediately applied to the canopy for the purpose of loosening mature fruit (Burns et al., 2003; Pozo and Burns 2000; Pozo et al., 2004). Preparation of solutions should occur in the field immediately before application to prevent loss of gaseous 1-MCP. The wettable powder is dissolved in the 

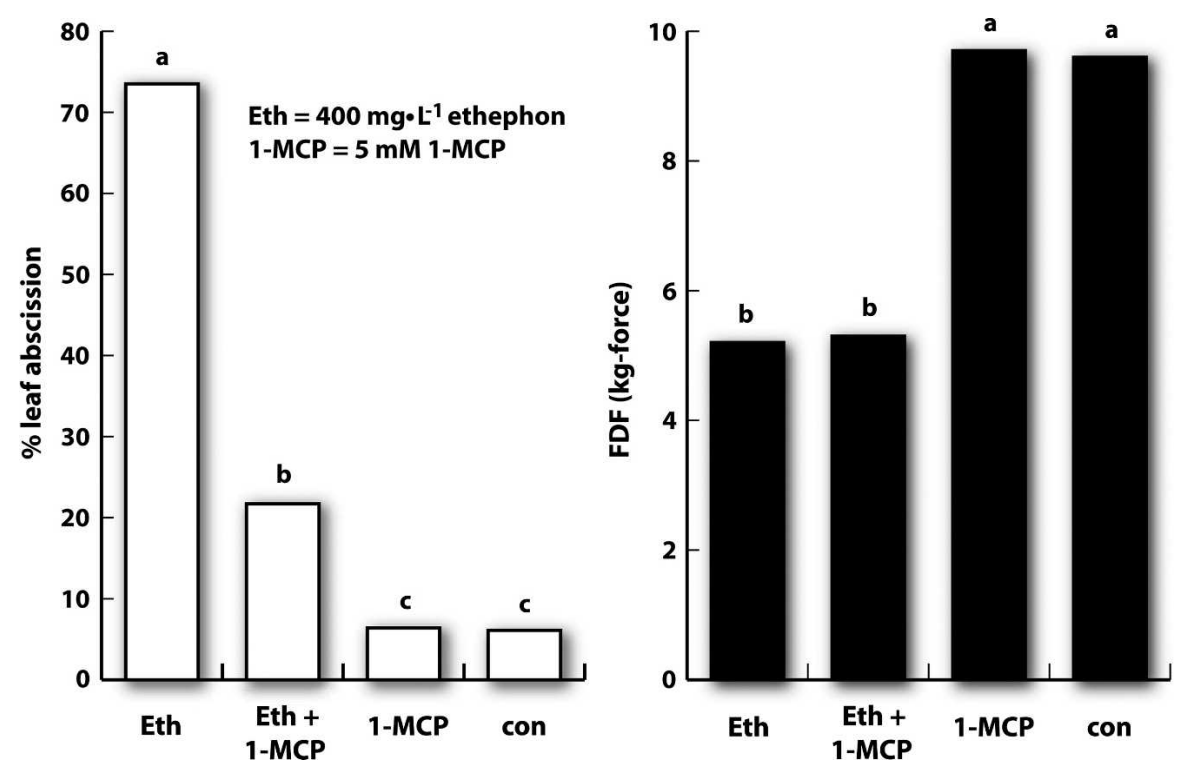

Fig. 3. Leaf abscission (\%, left graph) and fruit detachment force (FDF, right graph) 30 and $5 \mathrm{~d}$, respectively, after application of $5 \mathrm{~mm} 1$-methylcyclopropene $(1-\mathrm{MCP})+400 \mathrm{mg} \cdot \mathrm{L}^{-1}$ ethephon, 400 $\mathrm{mg} \cdot \mathrm{L}^{-1}$ ethephon, $5 \mathrm{~mm} 1-\mathrm{MCP}$, and adjuvant $(0.1 \%$ Kinetic) in 'Valencia' orange. Means with the same letter over the bar within the same graph are not significantly different $(P \leq 0.05)$. Con $=$ control.

Table 2. The effect of continuous ethylene exposure $\left(1 \mu \mathrm{L} \cdot \mathrm{L}^{-1}\right)$ for periods up to 1 week $(168 \mathrm{~h})$ on percentage $(\%)$ cumulative leaf loss and percentage fruit drop in potted calamondin citrus plants (Citrus madurensis). ${ }^{\mathrm{z}}$

\begin{tabular}{llrrr}
\hline & \multicolumn{2}{c}{ Percentage cumulative leaf loss } & & Percentage fruit drop $^{\mathrm{y}}$ \\
\cline { 2 - 3 } & $24 \mathrm{~h}$ & $48 \mathrm{~h}$ & $168 \mathrm{~h}$ & $168 \mathrm{~h}$ \\
\hline Ethylene & $1.1 \mathrm{a}$ & $34.2 \mathrm{a}$ & $81.5 \mathrm{a}$ & $72.3 \mathrm{a}$ \\
Ethylene + 1-MCP & $1.6 \mathrm{a}$ & $6.1 \mathrm{a}$ & $33.3 \mathrm{~b}$ & $70.1 \mathrm{a}$ \\
\hline
\end{tabular}

${ }^{\mathrm{z}}$ Data taken from Burns et al. (2003).

${ }^{\mathrm{y}}$ Means followed by the same letter are not significantly different $(P \leq 0.05)$.

$1-\mathrm{MCP}=1$-methylcyclopropene.

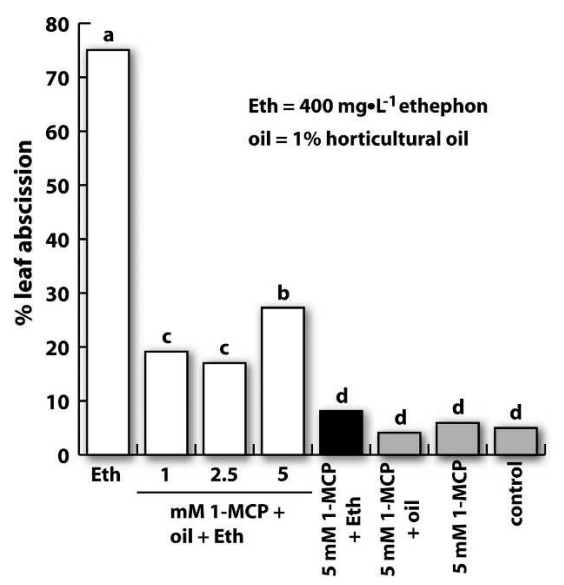

Fig. 4. Leaf abscission (\%) after application of 1-methylcyclopropene (1-MCP), 1-MCP + $400 \mathrm{mg} \cdot \mathrm{L}^{-1}$ ethephon, $400 \mathrm{mg} \cdot \mathrm{L}^{-1}$ ethephon, or adjuvant ( $0.1 \%$ Kinetic) $30 \mathrm{~d}$ after application. Horticultural oil (1\%; Growers 435 oil) was added to $1,2.5$, and $5 \mathrm{~mm} 1$-MCP treatments combined with ethephon or with $5 \mathrm{~mm} 1-\mathrm{MCP}$. Means with the same letter over the bar are not significantly different $(P \leq 0.05)$.

ethephon solution with minimal solution agitation, because excessive agitation can result in loss of 1-MCP. Once the powder is completely dissolved, the spray vessel is closed and the ethephon/1-MCP mixture applied within 5 to $10 \mathrm{~min}$ of preparation.
High-pressure application and small droplet sizes must be avoided, because these conditions result in loss of 1-MCP to the atmosphere. Success in citrus has been achieved with high-volume applications delivered at low pressure and large spray droplet sizes (Pozo et al., 2004).

Development of a sprayable formulation of 1-MCP would facilitate its field use for ethylene-related effects in horticultural commodities. AgroFresh has tested a sprayable 1-MCP formulation that has shown promise in apple to improve fruit set. In citrus, attempts to retard loss of the volatile a.i. by incorporating 1\% horticultural oil (Growers 435 Soluble Oil; Growers Fertilizer Corporation, Lake Alfred, FL) in the spray tank has not been successful in improving efficacy of 1-MCP (Fig. 4). A sprayable formulation of 1 -MCP for preharvest use may become a reality as research and formulation work continues and additional commercial benefits are demonstrated.

\section{SUMMARY AND CONCLUSION}

Remarkable postharvest benefits have been shown in commercial horticultural commodities by using 1-MCP to minimize the negative effects of ethylene (Blankenship and Dole, 2003). In addition to postharvest application, the potential to improve yield and quality of commodities by preharvest 1MCP application shows promise. Increasing selectivity of ethephon applications by inhibiting leaf drop with 1-MCP demonstrates its potential for commodity improvement with preharvest applications.

\section{Literature Cited}

Blankenship, S. and J.M. Dole. 2003. 1-Methylcyclopropene: A review. Postharvest Biol. Technol. 28:1-25.

Burns, J.K., L.V. Pozo, R. Yuan, and B. Hockema. 2003. Guanfacine and clonidine reduce defoliation and phytotoxicity associated with abscission agents. J. Amer. Soc. Hort. Sci. 128: 42-47.

Byers, R.E., D.H. Carbaugh, and L.D. Combs. 2005. Ethylene inhibitors delay fruit drop, maturity, and increase fruit size of 'Arlet' apples. HortScience 40:2061-2065.

Chow, B. and P. McCourt. 2006. Plant hormone receptors: Perception is everything. Gene Devel. 20:1998-2008.

Hall, A.E., J.L. Findell, G.E. Schaller, E.C. Sisler, and A.B. Bleecker. 2000. Ethylene perception by the ERS1 protein in Arabidopsis. Plant Physiol. 123:1449-1457.

Klee, H.J. 2002. Control of ethylene-mediated processes in tomato at the level of receptors. J. Expt. Bot. 53:2057-2063.

Nakano, R., E. Ogura, Y. Kubo, and A. Inaba. 2003. Ethylene biosynthesis in detached young persimmon fruit is initiated in the calyx and modulated by water loss from the fruit. Plant Physiol. 131:276-286.

O’Malley, R.C., F.I. Rodriguez, J.J. Esch, B.M. Binder, P. O'Donnell, H.J. Klee, and A.B. Bleecker. 2005. Ethylene-binding activity, gene expression levels, and receptor system output for ethylene receptor family members from Arabidopsis and tomato. Plant J. 41: 651-659.

Porat, R., X. Feng, M. Huberman, D. Galili, R. Goren, and E.E. Goldschmidt. 2001. Gibberellic acid slows postharvest degreening of 'Oroblanco' citrus fruits. HortScience 36: 937-940.

Porat, R., B. Weiss, L. Cohen, A. Dauss, R. Goren, and S. Droby. 1999. Effects of ethylene and 1-methylcyclopropene on the postharvest quality of 'Shamouti' oranges. Postharvest Biol. Technol. 15:155-163.

Pozo, L. and J.K. Burns. 2000. Ethylene action inhibitors reduced Ethrel-induced leaf drop and gummosis in citrus. Proc. Intl. Soc. Citricult. IX Congr. 1:578-579.

Pozo, L., R. Yuan, I. Kostenyuk, F. Alferez, G. Zhong, and J.K. Burns. 2004. Differential effects of 1-methylcyclopropene on citrus leaf and mature fruit abscission. J. Amer. Soc. Hort. Sci. 129:473-478.

Sisler, E.C. 2006. The discovery and development of compounds counteracting ethylene at the receptor level. Biotechnol. Adv. 24:357367.

Warner, H.L. and A.C. Leopold. 1969. Ethylene evolution from 2-chloroethylphosphonic acid. Plant Physiol. 44:156-158.

Watkins, C.B. 2006. The use of 1-methylcyclopropene (1-MCP) on fruit and vegetables. Biotechnol. Adv. 24:389-409.

Yuan, R. and J.K. Burns. 2004. Temperature factor affecting the abscission response of mature fruit and leaves to CMN-pyrazole and ethephon in 'Hamlin' oranges. J. Amer. Soc. Hort. Sci. 129:287-293.

HortScience Vol. 43(1) February 2008 